Historic, Archive Document

Do not assume content reflects current scientific knowledge, policies, or practices. 

R E C I I N D nod. 1932

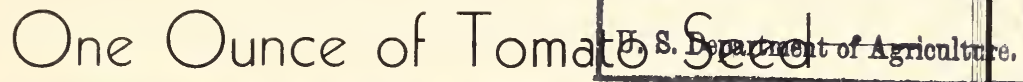

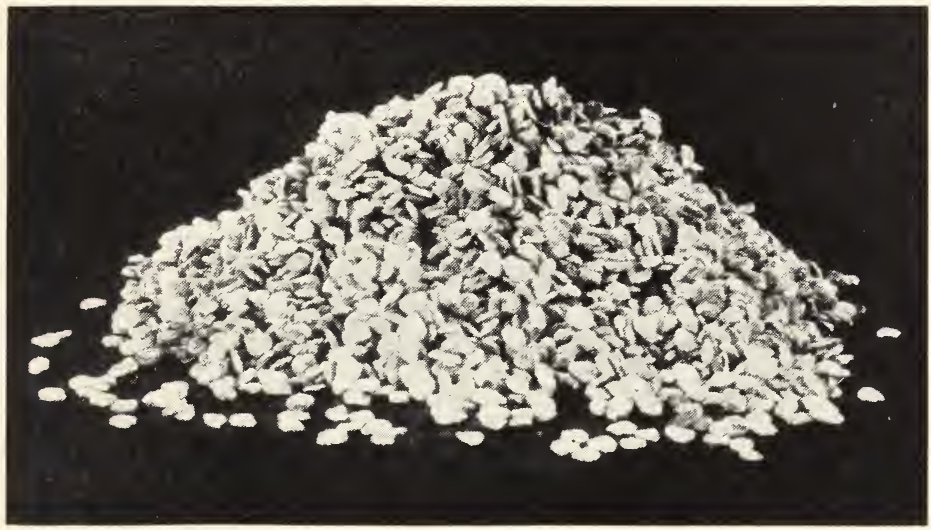

Only a handful-yet it has more than four thousand seeds. Each seed will be a "chip off the old block". The factors of variety, carliness, quality and prolificacy that will make or lose your profit are already determined - now, before the seed is even sown.

PLANT THE BEST SEED YOU CAN BUY. IT WILL PAY YOU.

$$
\begin{aligned}
& \text { H. P. LANGDON \& SON } \\
& \text { "Your Tomato Seedmen" } \\
& \text { CONSTABLE, N. Y. }
\end{aligned}
$$




\section{ADIRONDACK EARLIANA}

(120 DAYS, RED)

The Adirondack Strain of Earliana has had twenty-seven generations of breeding toward one ideal-extra early fruit of real market quality.

It is extra early; the earliest market variety of which we know. The fruit has given up much of the cussedness of the old type Earliana; it is smooth, quite deep, and firm. Seed cells are small and with thick walls. The color is a good hearty red extending, for an Earliana, remarkably well back toward the stem. The vines, though compact, are vigorous and prolific.

While the Earliana variety has its limitations, as has the extremely early type of any fruit, an improved strain such as this can make you money. Over most of the country the demand is strong-and the price high-for the first home grown tomatoes.

Getting first on the market is partly in knowing how, and then using that knowledge. Start, of course, with seed that will appreciate what you do for it. Read all you can about growing tomatoes. Experiment in a small way with the methods of other folks; perhaps you can adopt some of them to advantage.

The idea that the use of acid phosphate tends to hasten maturity is more than a theory; it is a fact that has been demonstrated over and over. Technical Bulletin No. 28 from New Hampshire gives some interesting results from a number of field tests along this line.

Because the first early plants are well advanced in maturity when set in the field, therefore easily checked, and because the ground is yet cool and with little available nitrogen, the use of nitrate water when setting is of especial benefit to this early crop.

Plan your sowing schedule so that you may have stocky, vigorous plants ready to blossom when setting time comes. And give them room, right from the seed bed. A soft, spindling plant may mature a crop of sorts, but the real tomatoes come on plants which have had a chance to properly develop. This is especially true with extra early varieties. 


\section{Price of Langdon's Twenty-seven Year Selection and Line Bred}

\section{ere \\ ADIRONDACK EARLIANA}

No. 1-Run of the field. 1/4 Oz., 25c;1/2 Oz., 40c; 1 Oz., 60c; 2 Oz., $\$ 1.20 ; 4 \mathrm{Oz} ., \$ 2.00 ; 8 \mathrm{Oz} ., \$ 3.60 ; 1$ pound, $\$ 6.40$.

No. 2-Double selection, by vine and fruit. $1 / 8$ Oz., 30c; $1 / 4$ Oz., 50c; $1 / 2$ Oz., 75c. Less than one-half pound, $\$ 1.25$ per Oz.; $1 / 2$ pound, $\$ 9.50$; one pound, $\$ 18.00$.

No. 3-Triple selection, by vine, fruit and interior. Our best. 1/8 Oz., $\$ 1.00 ; 1 / 4$ Oz., \$1.75; 1/2 Oz., \$2.50; 1 Oz., \$4.00; 4 Oz., \$15.00. No discount for less than four ounces.

Particular care is given the selection of this No. 3 Earliana. Earliness is of prime importance. Productiveness and vigor are essential. The quality of the fruit must have rigid inspection. After the selection of plant and fruit by outward appearance each fruit is cut individually, by hand, for inspection of the interior construction. A good market tomato will have few seeds and small cells, thick walls, no green or pithy core, will be well colored. Only those fruits showing a high standard of perfection in this, as well as in plant type, are used in the selection of this No. 3 Earliana.

The location at which this seed is grown is worthy of consideration. We are north of the Adirondacks, four miles from the Canadian Line, with a growing season of only about three months and a half free from frost, with generally cool days and many cold nights. This has without doubt been a factor in the improvement of these strains.

\section{OUR W A R R ANT Y All seed offered by us has been} tested and proven to be of good gemination. W' e will replace free of charge any seed which does not germinate under farrorable conditions, providing our stock bas not been sold out. Naturally. we can go no further than this in guaranteeing your success. 


\section{LATER VARIETIES}

BONNY BEST, Langdon strain

1/4 Oz. 1/2 Oz. $1 \mathrm{Oz} . \quad 2 \mathrm{Oz} .4 \mathrm{Oz} .8 \mathrm{Oz}$

(extra selected)

$\$ 1.00 \quad \$ 1.50 \quad \$ 2.50 \quad \$ 4.50 \quad \$ 8.00 \quad \$ 14.00$

BONNY BEST, Langdon strain

(selected)

$\begin{array}{llllll}.50 & .75 & 1.25 & 2.50 & 4.50 & 8.00\end{array}$

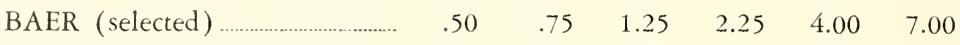

$\begin{array}{lllllll}\text { MARGLOBE (selected) ………....... } & .50 & .75 & 1.25 & 2.25 & 4.00 & 7.00\end{array}$

$\begin{array}{lllllll}\text { RED ROCK (selected) ……….......... } & .50 & .75 & 1.25 & 2.25 & 4.00 & 7.00\end{array}$

\section{ero}

\section{BONNY BEST (Langdon Strain)}

(126 DAYS, RED)

The improvement shown by this strain the past few years has been a source of much satisfaction to us, as well as of profit to our customers.

It has gained in earliness, yet retained its heavy yield. More-it has increased in yield. Several tests alongside other strains have given it first place in earliness, and usually first place in total crop as well. That means something, for Bonny Best has always been early enough for good money and noted as a heavy cropper.

The fruit qualities are fine. It picks uniformly a good packing size, a little larger than Bonny Best used to be. The old tendency toward cracking of the skin has largely been overcome. Smooth, round, well colored, firm-it is in every way an excellent packing tomato.

Unless you are seriously troubled by wilt you can use this strain of Bonny Best for second early with every confidence. It is just naturally the best.

If you have extra early soil give this strain a trial as first early. It will ripen a little behind the Adirondack Earliana, but the heavier yield may more than make up. If you have a piece of ground that is especially fertile, yet early and warm, try a few extra early plants 
pruned to one stem and staked. Pruning will hasten maturity by several days, on rich soil; you may want to go into it on a larger scale another year. Many growers are finding it profitable.

For canning crop the Bonny Best has been very popular. It is now being challenged by the Marglobe, however, even where wilt resistance need not be considered. The Marglobe, a little later in maturing, may produce a slightly heavier crop. It will require several extra pickings for the same bulk, though, for its ripening is delayed over quite a long picking season.

Marglobe has been advised to replace Bonny Best for greenhouse work. Where wilt is a factor Marglobe, being resistant, probably is better. If wilt is not troublesome Marglobe cannot, in our opinion, compete with this strain of Bonny Best in the greenhouse.

\section{BAER}

\section{(128 DAYS, RED)}

A good choice on dry, light soils, as it will set less fruit but mature them larger than Redhead or Bonny Best will do there. It is a thoroughly dependable variety. Smooth as an apple, not liable to crack around the stem, the stem cavity very shallow and the thickness of most of the fruit as great or greater than the diameter. A splendid improved strain.

\section{RED ROCK \\ (140 DAYS, RED)}

If you have loss from softening and cracking of mid-season and late varieties give this one a trial. It has a more firm fruit and thicker skin than any other variety we know.

The fruit is not as deep through as would be ideal, nor is it especially uniform in size, but these faults are far over-balanced by the great vigor and heavy yield of the vines and the deep red color and splendid table and shipping quality of the fruit. For a late midseason crop of special firmness, or for an extra late crop to mature after the first frosts the Red Rock is hard to beat. 


\section{MARGLOBE}

(142 DAYS, RED)

This introduction by Mr. F. J. Pritchard, of the Bureau of Plant Industry at Washington, has attracted much attention from all over the country.

It is a midseason variety of strong, though not excessive, vine growth, and matures a heavy crop. The fruit is distinctly globe shaped and a very attractive red in color. There is no depression at the stem end, no hard rind, and very little tendency toward cracking. It is an excellent shipper; its splendid table quality also commends it.

Marglobe is strongly resistant to Fusarium Wilt and to Nailhead Rust, two of the worst diseases which a tomato grower must combat. In the areas subject to infection they can be controlled only by the planting of resistant varieties. And the welcome given Marglobe -Florida changed over half her planting from Globe to Marglobe in two years time, wilt infested areas everywhere are turning to it more and more-such a welcome labels this as one of the most important introductions yet given the tomato grower.

$$
* * * *
$$

Remember, whether it's a report of last year's results, questions, some new idea worked out which you are willing to share, or just to say "hello", a letter from you is always interesting and welcome. We'll be looking forward to it.

Sincerely yours,

November, 1932.

H. P. LANGDON \& SON. 
